\title{
EFFECT OF SOME FUNGICIDES AND MULBERRY TOTAL SAPONIN EXTRACT ON FUNGAL AND BACTERIAL DISEASES
}

\author{
RAMSES, S. SH. AND RANIA A.ABDOU
}

Central Agricultural Pesticide Laboratory, ARC, Dokki, Giza

(Manuscript received 7 April 2009)

\begin{abstract}
Copper sulfate, thiophanate-methyl, carboxin and mulberry total saponin extract were added to PDA medium at concentrations of $25,50,100,200,400$ and $800 \mu \mathrm{g} / \mathrm{ml}$ for copper sulfate against Al. alternata, of $0.5,1,5,10,25$ and $50 \mu \mathrm{g} / \mathrm{ml}$ for thiophanatemethyl against $B$. cinerea, of $0.5,1,5,10,25,50$ and $100 \mu \mathrm{g} / \mathrm{ml}$ for carboxin against $R$. solani, S. rolfsii and $F$. oxysporum and of 250, 500,1000 and $2000 \mu \mathrm{g} / \mathrm{ml}$ for total saponin (TS) against the previous fungi as well as against Bacillus subtilis, Eschericha coli, Pseudomonas sp., Proteus vulgaris, Streptomyces sp. and Erwinia amylovora. The in vitro growth response (inhibition of linear growth), $\mathrm{EC}_{50}, \mathrm{EC}_{90}$ and slope of fungi and inhibition zone of bacteria were tested. Other experiments had been done in the greenhouse to test the effect of carboxin fungicide and mulberry TS extract on the change percentage of number healthy seedling, shoot \& root length and dry weight for tomato seedling after 35days from sowing in sterilized and infected soil with $S$. rolfsii fungus. The results of laboratory experiments indicated that both of TS and carboxin fungicide have the same trend which they were more toxic against $S$. rolfsii than both $R$. solani and $F$. oxysporum at different concentrations. Also thiophanate-methyl and copper sulfate fungicides were more toxic than TS against $B$. cinerea and Al. alternata, respectively. Total saponin at different concentrations, had moderate activity against Bacillus subtilis, Pseudomonas sp. and Proteus vulgaris, weak activity against Eschericha coli and Streptomyces $s p$. and no effect against Erwinia amylovora. The greenhouse experiment results indicated that adding TS or carboxin to tomato seeds before sowing in both of sterilized and infected soil, enhanced the growth seedlings system included shoot and root length. TS was more effective than carboxin on the growth seedlings system. While carboxin fungicide expressed moderate effect on the growth seedlings system, it represented the best highest percentage in healthy seedlings.
\end{abstract}

\section{INTRODUCTION}

Fungicides act as a major factor in the agricultural production as they are used to protect plants from several fungal diseases which accordingly lead to a lot of fungi such as Al. alternata (black rot), B. cinerea (gray mold), F. oxysporum (fusarium wilt), $R$. solani (damping-off) and $S$. rolfsii (southern blight).

As long as the improper use of fungicides causes many problems for both human beings and environment, so using some of the natural components that can 
fight against fungal and bacterial diseases is an essential matter that must be taken in consideration accordingly using saponin as an environmental non polluting fighter against both fungal and bacterial diseases.

Saponin is given to a group of natural glycosides occurring primarily but not exclusively in plants. It could be also produced by some marine animals, such as sea slug and starfish. Saponins are widely distributed in nature, being present in more than 1730 plant species belonging to 104 families. Of these species 627 were found to contain triterpenoid saponins and 127 to contain steroidal saponins i.e. triterpenoid saponins are most abundant in plant kingdom. The pentacyclic triterpenoid saponins are of rare occurrence in monocotyledons. They are more frequent in dicotyledons, being abundant in Caryophyllaceae, Sapindaceae, Polygolaceae, Sapotaceae and of common occurrence in Phytolaccaceae. Zygophullaceae, Oleaceae, Pspsbrtsvrsr, Sraliaceae, Linaceae, Rutaceae (Fenwick et al., 1991).

The present investigation was undertaken with the aim to study the biological activities of total saponin isolated from root bark of mulberry as an antifungal and antibacterial agent.

\section{MATERIALS AND METHODS}

\section{Materials:}

\section{Total Saponin}

Total saponin was prepared according to Ukpabi and Ukpabi, (2003). Root bark of mulberry was dried airy and ground to fine powder. The powder was soaked in petroleum ether $\left(40-60^{\circ} \mathrm{C}\right)$ for 24 hours to remove fats. The defatted powder was extracted with $50 \%$ aqueous methanol till exhaustion. The methanolic extract was reextracted with $n$-butanol several times. The butanolic extract was evaporated till dryness. The residue was dissolved in small amount of alcohol. Then, the total saponin precipitated by addition of large amount of acetone $(1: 5 \mathrm{v} / \mathrm{v})$.

\section{Bacterial strains}

Antibacterial activity of total saponin was investigated against Bacillus subtilis, Eschericha coli, Pseudomonas sp., Proteus vulgaris, Streptomyces sp. and Erwinia amylovora. All tested bacterial strains were maintained on nutrient agar medium (Oxiod) and were subcultured every two weeks.

\section{Fungal strains}

Antifungal activity of total saponin and fungicides (shown in Table 1) was investigated against Alternaria alternata, Botrytis cinerea, Fusarium oxysporum, Rhizoctonia solani and Sclerotium rolfsii. All tested fungal strains were maintained on 
Potato Dextrose Agar (PDA) medium (Oxiod CM 139) and were subcultured every two weeks.

Table 1. Trade, common and chemical names and active ingredient of tested fungicides.

\begin{tabular}{|c|c|c|c|}
\hline Traditional name & $\begin{array}{c}\text { Common name \& } \\
\text { Active ingredient }\end{array}$ & Chemical name & Formulation \\
\hline Del cup 6\% & $\begin{array}{c}\text { Copper sulfate } \\
(23.5 \%)\end{array}$ & Copper sulfate pentahydrate & Liquid \\
\hline Topsin-M 70\% & $\begin{array}{c}\text { Thiophanate-methyl } \\
(70 \%)\end{array}$ & $\begin{array}{c}\text { Dimethyl (1,2phenylene) bis } \\
\text { (iminocarbono-thioyl)bis } \\
\text { carbamate }\end{array}$ & Waterable powder \\
\hline Vitavax -T & Carboxin & $\begin{array}{c}\text { 5,6-dihydro-2-methyl - 1,4- } \\
\text { oxathi-ine-3-carboxyamide } \\
\text { bis (dimethyl thio-carbamayl) } \\
\text { disulfide }\end{array}$ & Waterable powder \\
\hline
\end{tabular}

\section{Methods:}

\section{Laboratory experiments}

\section{Antibacterial activity}

Antibacterial activity was determined by measuring the inhibition zone diameter (mm) using agar diffusion method according to Deans and Noble, (1995). Bacterial standard inoculums were prepared by adding $10 \mathrm{ml}$ of sterile water to slant culture (2-3days old) and shaken for $15 \mathrm{~min}$. The suspension of culture was collected and used as standard inoculums. $100 \mathrm{ml}$ of sterile medium were inoculated with $1 \mathrm{ml}$ standard inoculums of tested bacteria. Then, the inoculated medium was poured into sterilized Petri-dishes $(9 \mathrm{~cm})$. When the culture become solid, wells of $9 \mathrm{~mm}$ diameter were made by cork borer, then $50 \mu l$ of total saponin were transferred to each well. Dishes were incubated at $37^{\circ} \mathrm{C}$ for $24 \mathrm{hrs}$.

\section{Antifungal activity}

\section{Effect of different concentrations of tested fungicides and total saponin on the linear growth of some phytopathogenic fungi.}

This experiment was conducted to evaluate the effectiveness of total saponin and tested fungicides at different concentrations on the mycelia growth of $A /$. alternata, B. cinerea, F. oxysporum, R. solani and S. rolfsii. Fifty milliliters of PDA medium were transferred to conical flask $(150 \mathrm{ml})$ and autoclaved at $121^{\circ} \mathrm{C}$ for $20 \mathrm{~min}$. Adequate drops of $25 \%$ of lactic acid were added to medium after sterilization and before pouring in Petri-dishes to prevent bacterial contamination. Dilutions of each 
fungicide or total saponin were prepared as $\mathrm{w} / \mathrm{v}$ or $\mathrm{v} / \mathrm{v}$ by dissolving an appropriate amount of each of them in $10 \mathrm{mls}$ of sterile water. One milliliter containing each diluted fungicide and total saponin were added to the flasks containing PDA medium just before solidifying and shacked before pouring to get concentrations $25,50,100$, 200,400 and $800 \mu \mathrm{g} / \mathrm{ml}$ of copper sulfate against Al. alternata, $0.5,1,5,10,25$ and $50 \mu \mathrm{g} / \mathrm{ml}$ of thiophanate-methyl against $B$. cinerea, $0.5,1,5,10,25,50$ and $100 \mu \mathrm{g} / \mathrm{ml}$ of carboxin against R. solani, S. rolfsii and F. oxysporum and 250, 500, 1000 and $2000 \mu \mathrm{g} / \mathrm{ml}$ of total saponin against the previous fungi. All concentrations were expressed as active ingredient. A zero concentration treatment was prepared for each fungus used as untreated check. The different concentrations of each fungicide and total saponin were then poured in Petri-dishes $9 \mathrm{~cm}$ diameter. Dishes for each concentration were inoculated at the center with agar discs $(5 \mathrm{~mm}$ in diameter removed from the margins of 7days old culture) of the above mentioned pathogenic fungi. Five plates were used for each particular treatment as replicates. All plates were incubated at room temperature $\left(25 \pm 2^{\circ} \mathrm{C}\right)$. The radial growth of each tested fungus was measured in $\mathrm{mm}$ when its mycelial growth covered the surface of the medium in untreated check by calculating the average of two perpendicular diameters of the fungal growth (Abd El-Ghany, 2001). The data of linear growth fungi as affected by the treatments were tabulated. Also, the estimated effective concentration of the materials tested to give 50 and $90 \%$ inhibition radial growth $\left(\mathrm{EC}_{50}\right.$ and $\left.\mathrm{EC}_{90}\right)$ for each fungus was determined. The percentage of inhibition was calculated.

\section{Greenhouse experiment.}

\section{A. Preparation of pathogen fungus inoculum.}

For preparing fungal inocula (S. rolfsii), Erlenmeyer flasks $(500 \mathrm{ml})$ containing cornmeal-sand medium ( $25 \mathrm{~g}$ clean sand, $75 \mathrm{~g}$ corn and enough water to cover the prepared mixture) were autoclaved for $30 \mathrm{~min}$. at $121^{\circ} \mathrm{C}$, inoculated by 4 discs $(5 \mathrm{~mm})$ of fungus taken from the previous culture and then incubated at room temperature $\left(25 \pm 2^{\circ} \mathrm{C}\right)$ for two weeks.

\section{B. Pots sterilization.}

Plastic pots $(15 \mathrm{~cm}$ diameter) were sterilized by immersing in $10 \%$ formalin solution for $15 \mathrm{~min}$. and left for a week to get rid of formalin.

\section{Clay sterilization.}

Loam-soil were autoclaved an hour at $121^{\circ} \mathrm{C}$ three days frequency.

\section{Seed treatments.}

Tomato seed variety Castle rock was treated with total saponin or fungicide carboxin. The total saponin treated tomato seed were prepared by soaking tomato seed in $\mathrm{EC}_{50}$ of total saponin $(118.19 \mu \mathrm{g} / \mathrm{ml})$ for $5 \mathrm{mins}$, after that seeds were put on 
the filter paper to dry. Fungicide carboxin treated tomato seeds were prepared by mixing seeds with carboxin at recommend concentration $(3 \mathrm{~g} / \mathrm{kg}$ seeds) and glue suspension as adhesive material in closed glass container and vigorously shake-up 10 mins. Seeds were put on filter paper to dry.

\section{E. Experiment design.}

An experiment was carried out under greenhouse conditions. Plastic pots were divided into two groups each of 30pots. The pots in the first group were filled with $750 \mathrm{~g}$ sterilized uninfected loam-soil per pot. The pots in the second group were filled with the same amount of sterilized loam-soil after infected by mixing it with the prepared fungal inocula of $S$. rolfsii at $3 \%$ of soil weight $(\mathrm{w} / \mathrm{w})$ and watered regularly for ten days before sowing to insure the distribution and growth of inoculums. (Abd El-Ghany, 2001). Each group was divided into three subgroups each of ten pots as follows:

(I) Pots were sown with untreated tomato seeds (untreated check).

(II) Pots were sown with total saponin-treated tomato seeds.

(III) Pots were sown with carboxin-treated tomato seeds.

Each pot was sown with 5 tomato seeds treated or untreated. After 35 days of sowing, results were calculated as the percent healthy and unhealthy tomato seedlings and corrected with control group. Fresh and dry weight and shoot and root length of seedlings were determined.

\section{RESULTS AND DISCUSSION}

\section{Laboratory experiments}

\section{Antibacterial activity}

Effect of total saponin (TS) at different concentrations on growth of Bacillus subtilis, Eschericha coli. Pseudomonas sp., Proteus vulgaris, Streptomyces sp. and Erwinia amylovora.

Effect of total saponin (TS) at different concentrations i.e. 250, 500, 1000 and $2000 \mu \mathrm{g} / \mathrm{ml}$ on the growth of Bacillus subtilis, Eschericha coli, Pseudomonas sp., Proteus vulgaris, Streptomyces sp. and Erwinia amylovora, as represented in Table (2). Data in Table (2) proved that, Eschericha coli and Streptomyces sp. were not affected by TS at concentrations 500 and $250 \mu \mathrm{g} / \mathrm{ml}$, respectively. At different concentrations of TS caused inhibition zone of growth for Bacillus subtilis, Pseudomonas sp. and Proteus vulgaris. The highest effect was observed at high concentration of TS $(2000 \mu \mathrm{g} / \mathrm{ml})$ recording $16.0,16.0$ and $17.0 \mathrm{~mm}$ for Proteus vulgaris, Bacillus subtilis and Pseudomonas sp. respectively. While Erwinia amylovora was not affected by TS at different concentrations. 
The obtained results concluded that, TS at different tested concentrations had moderate activity against Bacillus subtilis, Pseudomonas sp. and Proteus vulgaris. Also, it had weak activity against Eschericha coli and Streptomyces sp. and no effect against Erwinia amylovora. These results were similar to that reported by Okunji et al., (1990), El-Hady et al., (1994) and Boguslavskii et al., (2001).

Table 2. Effect of total sponin (TS) on growth of Bacillus subtilis, Eschericha coli. Pseudomonas sp., Proteus vulgaris, Streptomyces $s p$. and Erwinia amylovora.

\begin{tabular}{|c|c|c|c|c|c|c|}
\hline $\begin{array}{l}\text { Concentration } \\
\qquad(\mu \mathrm{g} / \mathrm{ml})\end{array}$ & $\begin{array}{l}\text { Bacillus } \\
\text { subtilis }\end{array}$ & $\begin{array}{c}\text { Eschericha } \\
\text { coli }\end{array}$ & $\begin{array}{c}\text { Pseudomonas } \\
\text { sp. }\end{array}$ & $\begin{array}{l}\text { Proteus } \\
\text { vulgaris }\end{array}$ & $\begin{array}{c}\text { Streptomyces } \\
\text { sp. }\end{array}$ & $\begin{array}{c}\text { Erwinia } \\
\text { amylovora }\end{array}$ \\
\hline & \multicolumn{6}{|c|}{ Inhibition Zone in $(\mathrm{mm})$} \\
\hline 2000 & 16.0 & 8.0 & 17.0 & 16.0 & 10.5 & 0.0 \\
\hline 1000 & 15.0 & 5.0 & 15.0 & 14.0 & 7.0 & 0.0 \\
\hline 500 & 12.5 & 0.0 & 15.0 & 12.0 & 5.0 & 0.0 \\
\hline 250 & 10.5 & 0.0 & 10.0 & 10.0 & 0.0 & 0.0 \\
\hline 0 & 0.0 & 0.0 & 0.0 & 0.0 & 0.0 & 0.0 \\
\hline
\end{tabular}

Antifungal activity

Effect of total saponin (TS) and carboxin fungicide on the linear growth of R. solani, S. rolfsii and $F$. oxysporum

The effect of TS and carboxin fungicide at their tested concentrations on the linear growth of $R$. solani, $S$. rolfsii and F. oxysporum, is shown in Table (3). Results in Table (3) stated that, both TS and carboxin reduced the linear growth of three fungi and the highest concentration of both showed the highest inhibition of the fungal growth. The inhibition percentage of the linear growth of $R$. solani, $S$. rolfsii and $F$. oxysporum on PDA medium treated with $2000 \mu \mathrm{g} / \mathrm{ml}$ of TS was recorded $69.2,81.1$, and 48.3 , respectively, of that obtained in untreated medium. The results proved that $F$. oxysporum seems to be resistant or more tolerant to TS than $R$. solani and $S$. rolfsii. On the other hand, $S$. rolfsii was the most sensitive to TS at different tested concentrations comparing with $R$. solani and $F$. oxysporum. The $\mathrm{EC}_{50}$ values of TS were $118.9,1056.09$ and $2160.26 \mu \mathrm{g} / \mathrm{ml}$ against $S$. rolfsii, $R$. solani and $F$. oxysporum, respectively. These results were in agreement with those obtained by Lalitha and Venkataraman, (1991), Zehavi et al., (1993) and levy et al., (1999). 
Table 3. Effect of total saponin (TS) and carboxin fungicide at different concentrations on the linear growth of $R$. solani, S. rolfsii and F. oxysporum

\begin{tabular}{|c|c|c|c|c|c|c|c|c|c|}
\hline \multirow[b]{3}{*}{$\begin{array}{l}\text { Con. } \\
\text { (ppm) }\end{array}$} & \multicolumn{9}{|c|}{ R. solani } \\
\hline & \multicolumn{4}{|c|}{ Total Saponin (TS) } & \multicolumn{5}{|c|}{ Carboxin } \\
\hline & $\begin{array}{l}\text { Linear } \\
\text { growth } \\
\text { in mm }\end{array}$ & $\begin{array}{c}\% \\
\text { inhibition }\end{array}$ & $\begin{array}{l}\mathrm{EC}_{50} \\
(\mathrm{ppm})\end{array}$ & $\begin{array}{l}\text { Slope } \\
\text { value }\end{array}$ & $\begin{array}{l}\text { Con. } \\
\text { (ppm) }\end{array}$ & $\begin{array}{l}\text { Linear } \\
\text { growth } \\
\text { in } \mathrm{mm}\end{array}$ & $\begin{array}{c}\% \\
\text { inhibition }\end{array}$ & $\begin{array}{c}\mathrm{EC}_{50} \\
(\mathrm{ppm})\end{array}$ & $\begin{array}{l}\text { Slope } \\
\text { value }\end{array}$ \\
\hline 2000 & 27.70 & 69.2 & 1056.09 & 1.7 & 100 & 0.0 & 100 & 5.02 & 1.17 \\
\hline 1000 & 48.00 & 46.7 & & & 50 & 15.00 & 83.3 & & \\
\hline 500 & 63.80 & 29.1 & & & 25 & 25.00 & 72.2 & & \\
\hline 250 & 76.80 & 14.7 & & & 10 & 30.00 & 66.7 & & \\
\hline 0 & 90.00 & 0.0 & & & 5 & 45.00 & 50.0 & & \\
\hline- & - & - & & & 1 & 80.00 & 11.1 & & \\
\hline- & - & - & & & 0.5 & 90.00 & 0.0 & & \\
\hline- & - & - & & & 0 & 90.00 & 0.0 & & \\
\hline \multicolumn{10}{|c|}{ S. rolfsii } \\
\hline 2000 & 17.00 & 81.1 & 118.19 & 0.39 & 100 & 0.0 & 100 & 1.30 & 1.30 \\
\hline 1000 & 30.50 & 66.1 & & & 50 & 0.0 & 100 & & \\
\hline 500 & 37.00 & 58.9 & & & 25 & 7.00 & 92.2 & & \\
\hline 250 & 41.60 & 53.8 & & & 10 & 12.00 & 86.7 & & \\
\hline 0 & 90.00 & 0.0 & & & 5 & 22.00 & 75.6 & & \\
\hline- & - & - & & & 1 & 48.00 & 47.8 & & \\
\hline- & - & - & & & 0.5 & 65.00 & 27.8 & & \\
\hline- & - & - & & & 0 & 90.00 & 0.0 & & \\
\hline \multicolumn{10}{|c|}{ F. oxysporum } \\
\hline 2000 & 46.50 & 48.3 & 2160.26 & 1.86 & 100 & 10.00 & 88.9 & 10.01 & 1.18 \\
\hline 1000 & 66.10 & 26.6 & & & 50 & 20.00 & 77.8 & & \\
\hline 500 & 81.20 & 9.8 & & & 25 & 35.00 & 61.1 & & \\
\hline 250 & 85.30 & 5.2 & & & 10 & 40.00 & 55.5 & & \\
\hline 0 & 90.00 & 0.0 & & & 5 & 54.00 & 40.0 & & \\
\hline- & - & - & & & 1 & 75.00 & 16.7 & & \\
\hline- & - & - & & & 0.5 & 90.00 & 0.0 & & \\
\hline - & - & - & & & 0 & 90.00 & 0.0 & & \\
\hline
\end{tabular}

S. rolfsii was sensitive to fungicide carboxin at all concentrations under study. The linear growth of $S$. rolfsii was completely inhibited at concentration $50 \mu \mathrm{g} / \mathrm{ml}$. The inhibition percentage was 83.3 and 77.8 at the same concentration for $R$. solani and 
F. oxysporum, respectively. The linear growth of $R$. solani was also completely inhibited at concentration $100 \mu \mathrm{g} / \mathrm{ml}$. On the other hand, F. oxysporum seems to be more tolerant to this fungicide than $R$. solani and $S$. rolfsii as it was still growing even on medium treated with $100 \mu \mathrm{g} / \mathrm{ml}$ carboxin. The $\mathrm{EC}_{50}$ of carboxin values were 5.02 , 1.30 and $10.01 \mu \mathrm{g} / \mathrm{ml}$ against $R$. solani, S. rolfsii and $F$. oxysporum, respectively.

Data in Table (3) indicated that the fungicide carboxin was more toxic in vitro against $S$. rolfsii than $R$. solani and $F$. oxysporum. These results were in agreement with those obtained by Youssef, (1990), Henriquez and Montealegre, (1992) and Abd El-Ghany, (2001).

Results in Table (3) concluded that both of TS and carboxin fungicide were of the same trend as they were more toxic in vitro against $S$. rolfsii than $R$. solani and $F$. oxysporum at different concentrations.

\section{Effect of total saponin (TS) and thiophanate-methyl fungicide on the linear growth of B. cinerea .}

The effect of TS (at concentration of 250, 500, 1000 and $2000 \mu \mathrm{g} / \mathrm{ml}$ ) and thiophanate-methyl fungicide (at $0.5,1,5,10,25$ and $50 \mu \mathrm{g} / \mathrm{ml}$ ), on the linear growth of $B$. cinerea is shown in Table (4).

Data in Table (4) indicated that mycelia growth of $B$. cinerea was differentially inhibited on treated medium with TS at different concentrations $(250-2000 \mu \mathrm{g} / \mathrm{ml})$. Such effect was more pronounced with high concentration $(2000 \mu \mathrm{g} / \mathrm{ml})$ and the inhibition percentage was 61.4 of that obtained in untreated medium. The $\mathrm{EC}_{50}$ and $\mathrm{EC}_{90}$ values of TS against $B$. cinerea recorded 938.1 and $2931.6 \mu \mathrm{g} / \mathrm{ml}$, respectively. These results were in agreement with those observed by Singh et al., (1992) and Quidde et al., (1998). They suggested that saponins could be used for disease control in the field. The toxic action of saponins to fungi is associated with the ability of these compounds to complex with membrane sterols and causes pore formation.

The inhibitory effect of thiophanate-methyl fungicide at different concentrations $(0.5: 50 \mu \mathrm{g} / \mathrm{ml})$ on $B$. cinerea mycelia growth, is shown also in Table (4). Completely inhibition was achieved at concentration $50 \mu \mathrm{g} / \mathrm{ml}$, while, no effect was observed at concentration $0.5 \mu \mathrm{g} / \mathrm{ml}$. The $\mathrm{EC}_{50}$ and $\mathrm{EC}_{90}$ values recoded 0.89 and $25.0 \mu \mathrm{g} / \mathrm{ml}$, respectively.

Data in Table (4) proved that, thiophanate-methyl fungicide was more toxic in vitro than TS against $B$. cinerea. 
Table 4. Effect of total saponin (TS) and thiiophanate-methyl at different concentrations on the linear growth of $B$. cinerea

\begin{tabular}{|c|c|c|c|c|c|}
\hline $\begin{array}{c}\text { Concentration } \\
\text { (ppm) }\end{array}$ & $\begin{array}{l}\text { Linear growth } \\
\text { in } \mathrm{mm}\end{array}$ & $\begin{array}{c}\% \\
\text { inhibition }\end{array}$ & $\begin{array}{c}\mathrm{EC}_{50} \\
(\mathrm{ppm})\end{array}$ & $\begin{array}{l}\mathrm{EC}_{90} \\
(\mathrm{ppm})\end{array}$ & $\begin{array}{l}\text { Slope } \\
\text { value }\end{array}$ \\
\hline \multicolumn{6}{|c|}{ Total Saponin (TS) } \\
\hline 2000 & 34.70 & 61.4 & & & \\
\hline 1000 & 42.00 & 53.3 & & & \\
\hline 500 & 55.80 & 38.0 & 938.1 & 2931.6 & 1.39 \\
\hline 250 & 67.80 & 14.7 & & & \\
\hline 0 & 90.00 & 0.0 & & & \\
\hline \multicolumn{6}{|c|}{ Thiophanate-methyl } \\
\hline 50 & 0.00 & 100 & & & \\
\hline 25 & 9.00 & 90 & & & \\
\hline 10 & 15.00 & 83.4 & 0.89 & 25.0 & 1.49 \\
\hline 5 & 28.00 & 68.9 & & & \\
\hline 1 & 40.00 & 55.6 & & & \\
\hline 0.5 & 90.00 & 0.0 & & & \\
\hline 0 & 90.00 & 0.0 & & & \\
\hline
\end{tabular}

Effect of total saponin (TS) and copper sulfate fungicide on the linear growth of Al. alternata.

Data in Table (5) proved that, the reduction of the linear growth of $A /$. alternata moderately increased with high concentrations of TS $(1000$ and $2000 \mu \mathrm{g} / \mathrm{ml})$. At $250,500,1000$ and $2000 \mu \mathrm{g} / \mathrm{ml}$ of $\mathrm{TS}$, the inhibition percentages of the linear growth of this fungus recorded 15.6, 18.6, 31.3 and 50.0, respectively. The $\mathrm{EC}_{50}$ and $\mathrm{EC}_{90}$ values were 2000 and $4672.84 \mu \mathrm{g} / \mathrm{ml}$, respectively. These results were in agreement with those reported by Singh et al., (1992). They demonstrated that saponin B from oats at $2.5 \mathrm{mg} / \mathrm{ml}$ was highly effective against growth of Alternaria $s p$. They suggested that saponins could be used for disease control in the field.

On the other hand, the reduction of the linear growth of Al. alternata was pronounced with high concentrations of copper sulfate (200 and $400 \mu \mathrm{g} / \mathrm{ml}$ ). Completely inhibition of fungus growth was achieved at $800 \mu \mathrm{g} / \mathrm{ml}$. The $\mathrm{EC}_{50}$ and $\mathrm{EC}_{90}$ values were 182.81 and $620.12 \mu \mathrm{g} / \mathrm{ml}$, respectively. This result was in agreement with those recoded by Dewez et al., (2005). They reported that copper sulfate is commonly used as fungicide in agriculture practice to protect fruits and vegetable crops. 
Table 5. Effect of total saponin (TS) and copper sulfate fungicide at different concentrations on the linear growth of Al. alternata.

\begin{tabular}{|c|c|c|c|c|c|}
\hline $\begin{array}{c}\text { Concentration } \\
(\mathrm{ppm})\end{array}$ & $\begin{array}{l}\text { Linear growth } \\
\text { in } \mathrm{mm}\end{array}$ & $\begin{array}{c}\% \\
\text { inhibition }\end{array}$ & $\begin{array}{l}\mathrm{EC}_{50} \\
(\mathrm{ppm})\end{array}$ & $\begin{array}{l}\mathrm{EC}_{90} \\
(\mathrm{ppm})\end{array}$ & $\begin{array}{l}\text { Slope } \\
\text { value }\end{array}$ \\
\hline \multicolumn{6}{|c|}{ Total Saponin (TS) } \\
\hline 2000 & 45.00 & 50.0 & & & \\
\hline 1000 & 61.80 & 31.3 & & & \\
\hline 500 & 73.20 & 18.6 & 2000 & 4672.89 & 1.07 \\
\hline 250 & 76.00 & 15.6 & & & \\
\hline 0 & 90.00 & 0.0 & & & \\
\hline \multicolumn{6}{|c|}{ Copper sulfate } \\
\hline 800 & 0.00 & 100 & & & \\
\hline 400 & 24.00 & 66.0 & & & \\
\hline 200 & 40.00 & 55.6 & 182.81 & 620.12 & 2.33 \\
\hline 100 & 65.00 & 27.8 & & & \\
\hline 50 & 80.00 & 11.1 & & & \\
\hline 25 & 90.00 & 0.0 & & & \\
\hline 0 & 90.00 & 0.0 & & & \\
\hline
\end{tabular}

\section{Greenhouse experiment}

Effect of total saponin (TS) and carboxin on number of healthy seedlings' shoot \& root length and dry weight in tomato seedlings.

Effect of TS and carboxin on the change percentage (increase/decrease) of number of healthy seedlings' shoot \& root length and dry weight for tomato seedlings after 35days from sowing in sterilized and infected soil is shown in Table (6).

Sowing tomato seeds treated with TS or carboxin in sterilized soil expressed increase in number of healthy seedlings compared to untreated seeds after 35days of sowing. Such increase was low significant $(p<0.05)$ in case of seeds treated with carboxin which reached $12.5 \%$ of that obtained in untreated seeds. On the other hand, sowing tomato seeds in soil infected with $S$. rolfsii induced highly decrease in number healthy seedlings comparing with those sown in sterilized soil which recorded $15.0 \pm 1.3$ and $40.0 \pm 2.3$ seedling, respectively, after 35days of sowing. Adding TS or carboxin to seeds before sowing in infected soil induced highly significant $(p<0.001)$ increase in number of healthy seedlings compared to untreated seeds. Such increase was more pronounced in case of carboxin which recorded $133.3 \%$ of that obtained in untreated seeds after 35 days of sowing.

Data in Table (6) proved that, the increase of shoot and root length for tomato seedlings was observed after 35days of sowing seeds treated with TS or 
carboxin in sterilized soil comparing with untreated. This effect was moderate significant $(p<0.01)$ and noticeable in case of treatment with TS and the change percentages of shoot and root length were 22.7 and 20.0, respectively, of that observed in untreated seeds. While, sowing tomato seeds in infected soil caused greatly decrease in shoot and root length $(5.42 \pm 0.3$ and $1.2 \pm 0.5 \mathrm{~cm})$ comparing with those sown in sterilized soil $(13.2 \pm 1.3$ and $2.5 \pm 0.2 \mathrm{~cm})$, respectively. Treating TS or carboxin to tomato seeds before sowing in infected soil induced significant increase in shoot and root length compared to untreated. Such increase was highly $(p<0.01)$ and moderate $(p<0.01)$ significant in case of TS and carboxin, respectively. The highest increase in shoot and root length were observed in case of sowing seeds treated with TS which reached 88.6 and $83.3 \%$, respectively, of that detected in untreated. While, in case of carboxin, the percentage of change in shoot and root length were recorded 36.0 and 50.0, respectively, of that obtained in untreated, after 35days of sowing in infected soil. In generally, shoot and root length of tomato seedlings in sterilized soil was still taller than those in infected soil.

Sowing tomato seeds treated with TS or carboxin in sterilized soil, resulted in significant increase in dry weight of seedlings compared to untreated tomato seeds after 35days of sowing. Such increase was moderate significant $(p<0.01)$ and pronounced in case of seeds treated with TS comparing with untreated which reached $0.33 \pm 0.001$ and $0.22 \pm 0.001 \mathrm{~g} /$ seedling, respectively. On the other hand, sowing tomato seeds in soil infected with $S$. rolfsii induced sharply decrease in dry weight of seedlings comparing with those sown in sterilized soil which equal to $0.083 \pm 0.001$ and $0.22 \pm 0.001 \mathrm{~g} /$ seedling, respectively. While, adding TS or carboxin to seeds before sowing in infected soil, caused significant increase in dry weight of seedlings compared to untreated seeds after 35days of sowing. This increase was highly significant $(p<0.001)$ and pronounced in case of sowing seeds treated with TS which recorded $80.7 \%$ of that obtained in untreated. Although, treating TS or carboxin to tomato seeds before sowing in infected soil improved in the dry weight of seedlings comparing with untreated, the dry weight still lower than those sown in sterilized soil. 
Table 6. Effect of total saponin (I) and carboxin (II) on number healthy seedlings shoot \& root length and dry weight in tomato seedlings.

\begin{tabular}{|c|c|c|c|c|}
\hline \multirow[t]{2}{*}{ Tretments } & \multicolumn{2}{|c|}{ Sterilized soil } & \multicolumn{2}{|c|}{ Infected soil with $S$. rolfsii } \\
\hline & mean $\pm S E$ & $\%$ & mean $\pm S E$ & $\%$ \\
\hline \multicolumn{5}{|c|}{ Number of the healthy seedlings } \\
\hline Untreated & $40.0 \pm 2.3$ & 0.0 & $15.0 \pm 1.3$ & 0.0 \\
\hline I-treated & $42.0 \pm 4.1$ & 5.0 & $30.0 \pm 8.1^{* * *}$ & 100.0 \\
\hline II-treated & $45.0 \pm 3.2^{*}$ & 12.5 & $35.0 \pm 9.3 * * *$ & 133.3 \\
\hline \multicolumn{5}{|c|}{ Shoot length $(\mathrm{cm})$} \\
\hline Untreated & $13.2 \pm 1.3$ & 0.0 & $5.42 \pm 0.3$ & 0 \\
\hline I-treated & $16.2 \pm 2.5^{* *}$ & 22.7 & $10.22 \pm 1.2 * * *$ & 88.6 \\
\hline II-treated & $15.4 \pm 1.8$ & 9.8 & $7.37 \pm 1.0 * *$ & 36.0 \\
\hline \multicolumn{5}{|c|}{ Root length $(\mathrm{cm})$} \\
\hline Untreated & $2.5 \pm 0.2$ & 0.0 & $1.2 \pm 0.5$ & 0 \\
\hline I-treated & $3.0 \pm 0.1 * *$ & 20.0 & $2.2 \pm 0.8^{* * *}$ & 83.3 \\
\hline II-treated & $2.6 \pm 0.1$ & 4.0 & $1.8 \pm 0.4 * *$ & 50.0 \\
\hline \multicolumn{5}{|c|}{ Dry weight (g) } \\
\hline Untreated & $0.22 \pm 0.001$ & 0.0 & $0.083 \pm 0.001$ & 0 \\
\hline I-treated & $0.33 \pm 0.001^{* *}$ & 50.0 & $0.15 \pm 0.001 * * *$ & 80.7 \\
\hline II-treated & $0.29 \pm 0.001 *$ & 31.8 & $0.12 \pm 0.001^{* *}$ & 44.6 \\
\hline
\end{tabular}

Results are expressed as mean \pm SE for 5 replicates in each group.

$\%$ the percentage of change (increase/decrease).

$*$ significant $\mathrm{p}<0.05 \quad * * \mathrm{p}<0.01 \quad * * * \mathrm{p}<0.001$

From the above results it could be concluded that, adding TS or carboxin to tomato seeds before sowing in both of sterilized and infected soil, enhanced the growth seedlings system included shoot and root length. TS had more effect than carboxin on the growth seedlings system. While, carboxin fungicide expressed moderate effect on the growth seedlings system but it represented the best highest percentage in healthy seedlings. These results were similar to that recorded by ElDeeb and Ibrahim, (1998). They demonstrated that, the seed dressing fungicide carboxin significantly decreased pre- and post-emergence damping-off and pod rot diseases and gave the highest percentages of healthy survival plants. Also, Hammouda et al., (2001) might be interpret the role of fungicides and thyme extract in controlling soil borne pathogenic fungi that infect faba bean and their relationship with chitinase, peroxidase and phenolic compounds as antifungal substances in plants tissues and then subsequent increases in root \& shoot lengths and dry weight of plants. 


\section{REFERENCES}

1. Abd El-Ghany, R.E.A. 2001. Pathological studies on root-rot disease of peanut (Arachis hupogaea L.) in Egypt. Ph.D., Fac. of Agric., Zagazig Univ.p.50

2. Boguslavskii, V.M., T.I. Shirshova, S.A. Burtseva, S.Y. krepis and K.A. Panyushkina. 2001. Antimicrobial and antifungal activity of alfalfa saponins Buletinul Academiei De Stiinte 3:42-44.

3. Deans, S.G. and R.C. Noble. 1995. Antimicrobial and antioxidant properties of Syzgium aromaticum (L.) J. Flavour and Fragrance 10:323-328.

4. Dewez, D.,L. Geoffroy, G. Verrnet and R. popovic. 2005. Determination of photosynthetic and enzymatic biomarkers sensitivity used to evaluate toxic effects of copper and fludioxonil in alga Scenedesmus obliquus. Aquatic Toxicol. 74:150159.

5. El-Deeb, A.A. and E.M. Ibrahim. 1998. Integrated control of peanut root-rot, potrot diseases in Egypt J. Appl. Sc. 13(3):442-458

6. El-Hady, F.K.A., A.G. Hegazi, N. Ata and M.L. Enbaawy. 1994. Studies for determining antimicrobial activity of Solenostemma arge/ (Del) Hayne. Qatar Unvi. Sci. J. 14:138-142.

7. Fenwick, G.R., K.R. Price, C. Tsukamoto and K. Okubo. 1991. Saponins, In Saponins in Toxic Substances in Crop Plants,(Dmello F.J.P., Duffus C.M. and J. H. Duffus, editors). Cambridge: The Royal Society of Chemistry, PP.361,362.

8. Hammouda, A.M., I. Abd-El-Moneim, S.H. Abd-El-Ghani and M.A. Heweidy. 2001. Induced resistance in faba bean against rust disease by using natural products. Egypt J. Appl. Sci. 14(4):15-26.

9. Henriquez, S.J. and A.J. Montealegre. 1992. Chemical control of Sclerotium rolfsii. J. Phytopathol.73(11):5413-5418.

10. Lalitha, T. and L.V. Venkataraman. 1991. Antifungal activity and mode of action of saponins from Madhuca butyracea. Indian J. Experimental Biolo, 29(6):558-562.

11. Levy, M., U. Zehavi, M. Naim and I. Polacheck. 1999. Isolation, structure determination, synthesis and antifungal activity of a new native alfalfa-root saponin. Carbohydrate Res.193(1):115-123.

12. Okunji, C.O., C.N. Okeke, H.C. Gugnani and M.M. Iwu. 1990. An antifungal spirostanol saponin from fruit puple of Dracaena mannii. Inter. J. Crude Drug Res. 28(3):193-199. 
13. Quidde, T, A. Osbourn and P.Tudzynski. 1998. Detoxification of a-tomatine by Botrytis cinerea. Physiol. Mol. Plant Pathol.52:151-165.

14. Singh, U., B. Srivastava, K. Singh and V. Pandey. 1992. Antifungal activity of steroid saponins and sapogenins from Avena sativa and Costus speciosus. Naturalia Sao Paulo 17:71-77.

15. Ukpabi, U.H. and U.J. Ukpabi. 2003. Potential of seeds of Napoleona imperialis (P.beauv) as a source of hemolytic saponin and feed ingredients. Lifestock Research for Rural Development 15(12):103-112.

16. Youssef, R.M. 1990. A comparative study of the use of plant juice and fungicides for controlling damping-off disease of lentil. Al-Azhar J.Agric. Res. 13:63-76.

17. Zehavi, U., O. Ziv, M. Naim, R. Evron and I. Polacheck. 1993. Synthesis and antifungal activity medicagenic acid saponins on plant pathogens. Carbohudrate Res.244(1):161-169. 


\section{تأثثير بعض المبيدات الفطرية والصابونين الكلي \\ علي بعض الأمراض الفطرية والبكتيرية}

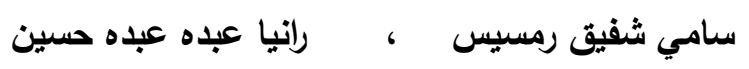

$$
\text { الدعمل المركزي للمبيدات - مركز البحوث الزراعية - الدقى - الجبية }
$$

الهدف الرئيسي من هذه الدراسة هو التعرف علي فعالية الصابونين الكلي المستخلص من قلف جذر شجرة التوت كمضاد للبكتبريا والفطريات الممرضة للنبات.

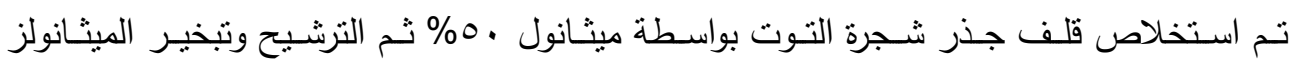

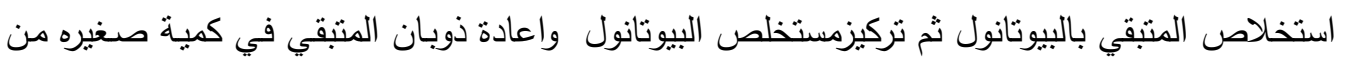

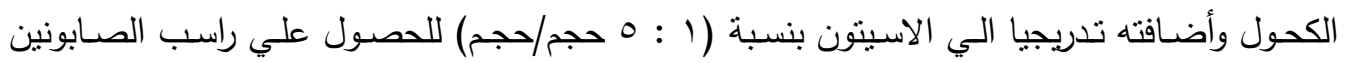

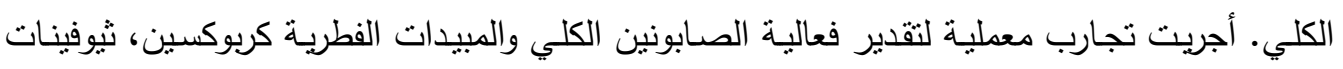

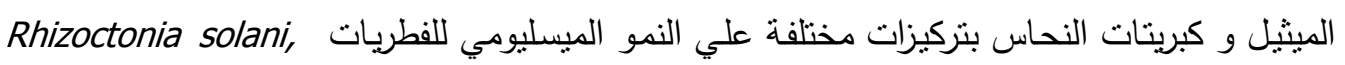
Sclerotium rolfsii, Fusarium oxysporum, Botrytis cinerea and Alternaia alternata Bacillus subtilis, استخدم الصـابونين الكلي كمضـاد للبكتيريا حيث اختبرت فعاليته ضد بكتيريا Eschericha coli, Pseudomonas sp., Proteus vulgaris, Streptomyces sp. and Erwinia amylovora

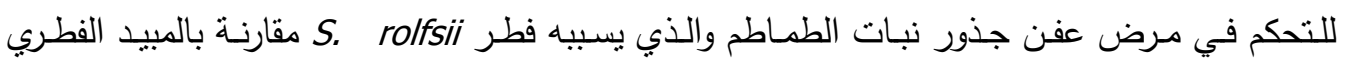
كربوكسين في تربة معقمـة واخري تم تلويثها بالفطر ـ أخذت قياسـات طول الجذور والبادرات والوزن

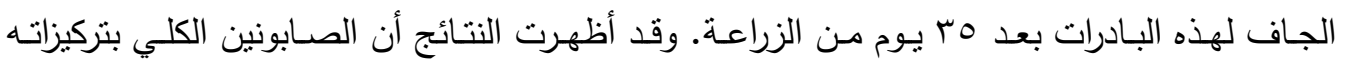

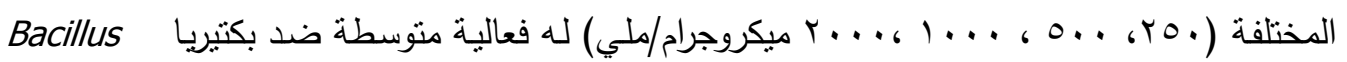
subtilis, Pseudomonas sp. and Proteus vulgaris. Eschericha coli and Streptomyces sp.

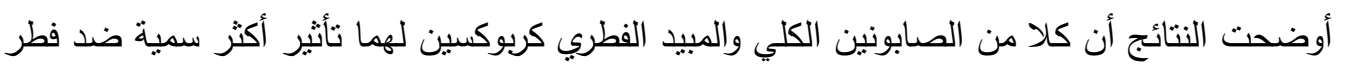

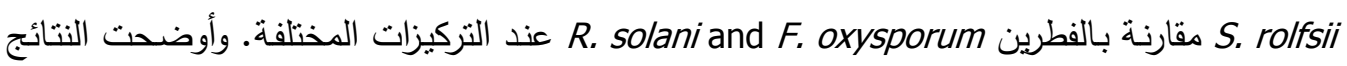

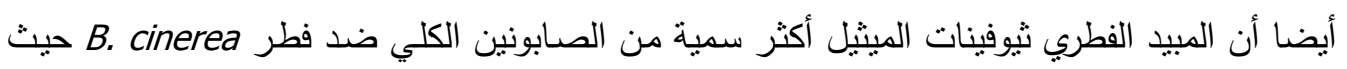

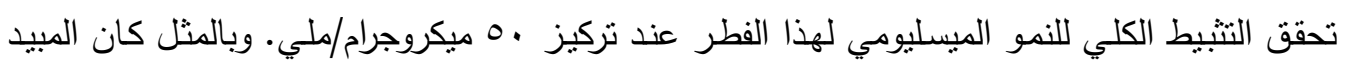
الفطري كبريتات النحاس أكثر سمية من الصابونين الكلي ضد فطر Al. alternata حيث تحقق التثبط

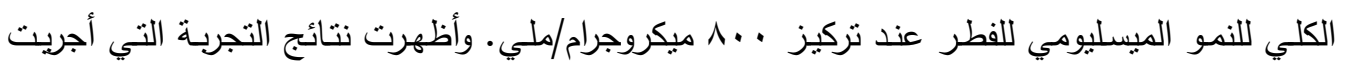

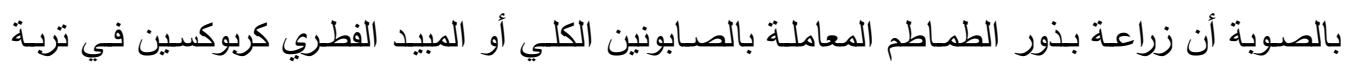

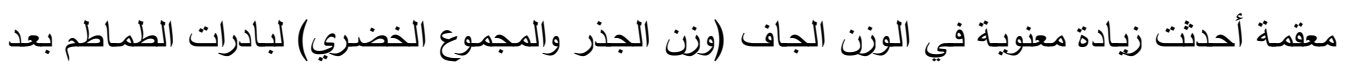

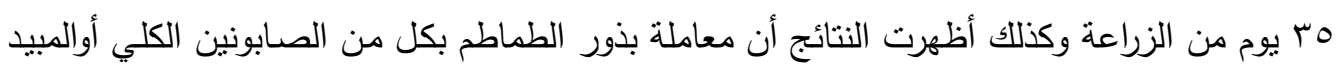
الفطر كربوكسين قبل زراعتها في تربة معدية بالفطر أحدثت تحسن ملحوظ في القياسات مقارنة بالبذور 